\title{
HYPOXIS COLLICULATA (HYPOXIDACEAE), A NEW SPECIES FROM MEXICO AND A KEY TO THE AMERICAN SPECIES WITH BLACK SEEDS
}

\author{
J. Gabriel SÁnCheZ-Ken
}

Universidad Nacional Autónoma de México, Instituto de Biología, Departamento de Botánica, 04510 México, D.F. México. sanchezken@ibiologia.unam.mx

\section{ABSTRACT}

A new species, Hypoxis colliculata from Oaxaca and Chiapas, México is presented here. It belongs to the group with black seeds and is separated from the other species by the colliculate sculpturing of the seeds.

Key words: black seeds, colliculate, Chiapas, Hypoxidaceae, Hypoxis colliculata, Mexico, Oaxaca, ornamentation.

\section{RESUMEN}

Se propone como nueva a Hypoxis colliculata, planta de Oaxaca y Chiapas, México. La especie se separa de las otras del grupo caracterizado por semillas negras en la ornamentación bulada de estas últimas.

Palabras clave: bulada, Chiapas, Hypoxidaceae, Hypoxis colliculata, México, Oaxaca, ornamentación, semillas negras.

The Hypoxidaceae R. Br. are a small family within the order Asparagales and together with other small families conform the sister group to the Orchidaceae, based on molecular and morphological data (Dahlgren et al., 1985; Rudall et al., 1998; Anónimo, 2003; Davis et al., 2004). In older classifications, Hypoxidaceae genera were classified within other families such as Amaryllidaceae J.St.-Hil. or Liliaceae Juss. (Baker, 1878; Cronquist, 1981). The family includes from seven to nine genera 
with approximately 200 species worldwide (Govaerts, 2009), found mostly in the southern hemisphere of the Old World and in North America.

The genus Hypoxis L. is the most diverse in the family with approximately 80-90 species distributed worldwide (Govaerts, 2007). There are several centers of diversity for the genus, with these found in Africa, Australia and Southeast Asia as well as the Americas. In the Americas there are about 15 species, with 13 located in the North American continent (Govaerts, 2009). The diversity in Mexico varies between seven and ten species depending on the authors. One of the first works that included the Mexican species was that of Brackett (1923), who reported seven species, three of them new at that time in Mexico. Later, McVaugh (1989) considered four species for the Novo-Galician region, with one new species and synonymized two of Brackett's species. More recently, checklists report nine species for Mexico (Espejo \& López, 1996; Villaseñor, 2004; Govaerts, 2007).

Apparently the circumscription of the genus does not have problems, but at the species level is a different matter. Some authors such as Brackett (1923) and McVaugh (1989) gave more importance to seed sculpturing; whereas Herndon (1992) and Nesom (1993) considered that the correlations between measurements of floral characters or other structures were also good diagnostic characters. Other vegetative or reproductive characters are diagnostic in defining some species such as the filiform leaf blades of $H$. juncea Sm. (Herndon, 1992) or the membranaceous tunic of the corm of $H$. decumbens L. (Huft, 1994); or the lack of sculpturing in the smooth seeds of $H$. lucens McVaugh (McVaugh, 1989). Nonetheless, in many other species vegetative and even reproductive (measurements of flowers and fruits) characters overlap, and therefore they cannot be diagnostic.

More recent studies of Wiland-Szymańska $(2001,2006)$ in African Hypoxis show that Brackett's appreciation of the morphology of the seeds was in the right direction to resolve the taxonomy of the species, although she stated that some type of seed sculpturing are present in more than one species.

As a result of a revision of the family Hypoxidaceae for the Flora of the Tehuacan - Cuicatlan Valley, I found the following new species and also the necessity to review the Mexican Hypoxis due to the lack of understanding of their taxonomy.

Hypoxis colliculata Sánchez-Ken sp. nov. Figs. 1, 2.

Cormi tunica membranacea, 1-2 vaginis aphyllis, plerumque fibris ad $1 \mathrm{~cm}$ longis, rectis vel flexuosis; foliorum laminae (4-)10-50 cm longae, 1.7-4 mm latae, 
lineares, 10-17-nervatae, sparsim pubescentes; scapi 1-3, 4-18 cm longi, 1-2 floribus per scapum; pedicelli longitudine flores et bracteas fere aequantes; bracteae florales 1-2 per florem; tepala 3-8(-10) $\mathrm{mm}$ longa, $1-2.5 \mathrm{~mm}$ lata, illa seriei interioris leviter breviora, lanceolato-linearia, 5-8-nervata; antherae 0.9-1.5 mm longae; semina 1.1$1.3 \mathrm{~mm}$ longa, $0.8-0.85 \mathrm{~mm}$ diam, oblongo-elliptica, nigra, nitida, superficie colliculata vel strumosa, cellulis 4-7-gonis, heteromorphis, heterodiametralibus, magnitudine variabili, $27 \times 50$ ad $44 \times 55 \mu \mathrm{m}$, arcte dispositis, truncatis vel leviter curvatis, non exfoliantibus, non iridiscentibus.

Corms 1.2-2 cm long, 0.5-1.1 cm wide, membranaceous tunic with 1-2 sheaths with no blades or the uppermost with a reduced blade up to $8 \mathrm{~cm}$ long, usually with short fibers up to $1 \mathrm{~cm}$ long, these curve, straight to flexuous, rhizome with white flesh, the outer part with packs of raphides; foliar sheaths included in the tunic, glabrous to sparsely pilose toward the apex, the trichomes 2-branched; blades (4-)10-50 cm long, 1.7-4 mm wide, linear, 10-17-nerved including first to third order nerves, midnerve projected abaxially, pilose, 2-4 lateral nerves projected abaxially, both surfaces sparsely pilose mostly towards the margins, density of hairs decreasing toward the apex, the hairs 2-branched; inflorescence a cyme; scapes 1-3, 4-18 cm long, flattened and glabrescent below, more densely pilose above, the hairs 2-branched, 1-2 flowers per scape; pedicels 1-9 mm long, densely pilose, the hairs 2-branched; floral bracts $0.25-1.1 \mathrm{~cm}$ long, ca. $0.2-0.3 \mathrm{~mm}$ wide, 1-2 per flower, with few hairs on the nerves; outer tepals 3-8(-10) mm long, 1-2.5 $\mathrm{mm}$ wide, lanceolate-linear, abaxially scarcely to densely pilose, usually with a tuft of hairs at the apex, the hairs 2-branched, adaxially glabrous, 5-8-nerved; inner tepals 3.4-7 mm long, 1.3-2.4 mm wide, glabrous on both surfaces, rarely with 3 lines of hairs below, the hairs 2-branched, 5-7-nerved; anthers 0.9-1.5 mm long, filaments 1-3 mm long; capsule 1.1-1.3 cm long, 2.5-3.5 mm wide, oblong-elliptic, sparsely to densely pilose, the hairs 2-branched; seeds 1.1-1.3 mm long, 0.8-0.85 $\mathrm{mm}$ diameter, oblong-elliptic, black, bright, surface colliculate or strumose, cells oblong-elliptic (Fig. 2), $27 \times 50$ to $44 \times 55 \mu \mathrm{m}$, not inflated or slightly so, short, heterodiametric, more or less homogeneous, anticlinal walls irregular and curved, compactly arranged, not exfoliative, not iridescent.

Type: Mexico, Oaxaca, distrito Nochixtlán, municipio San Miguel Chicahua, $8 \mathrm{~km}$ al NO de Amatlán, camino a Apoala, bosque de Quercus, $2440 \mathrm{~m}$, A. García-Mendoza, S. Franco \& A. Castañeda 7121 (holotype: MEXU; isotype: US3437652). 


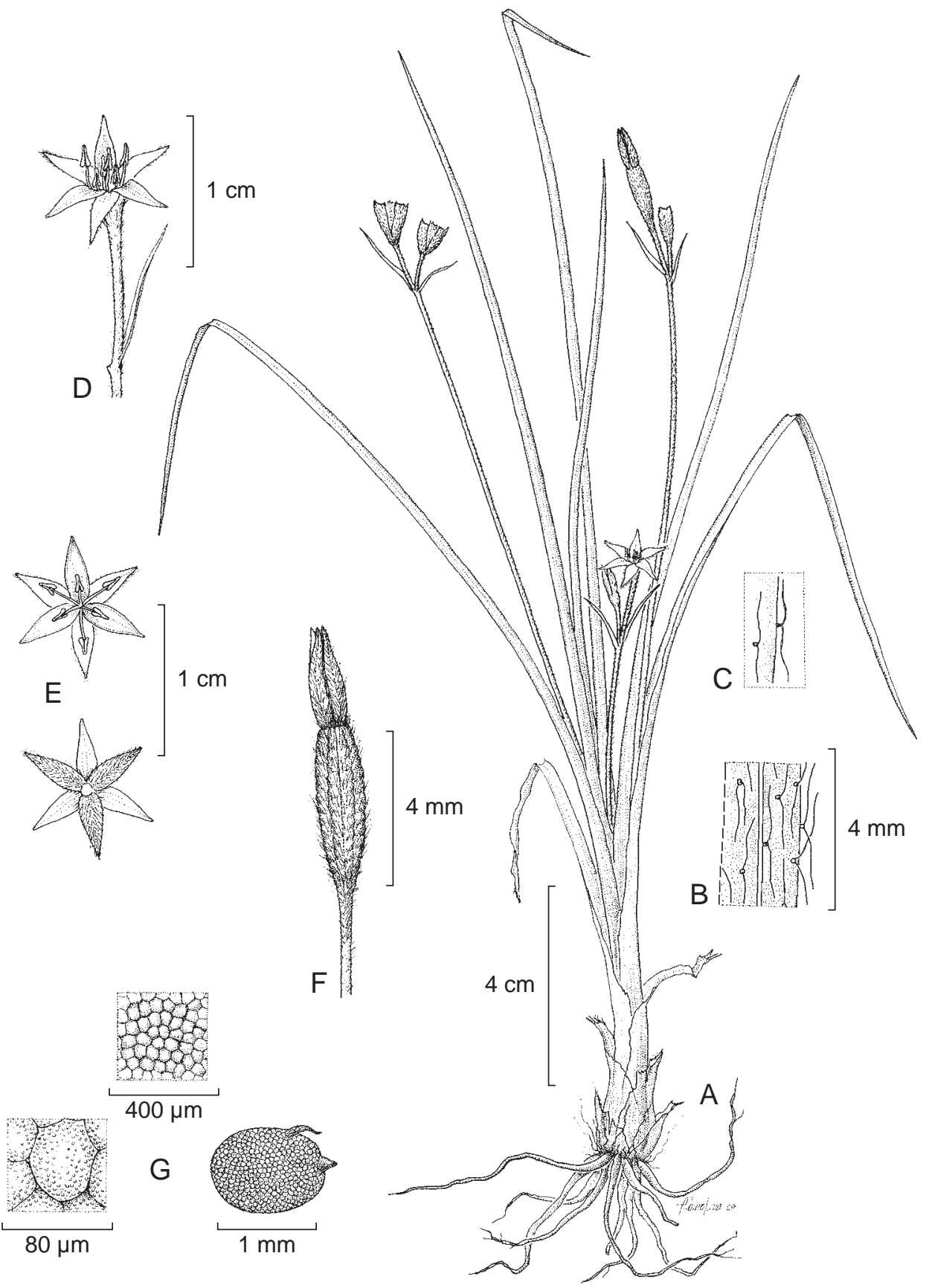

Fig. 1. Hypoxis colliculata A. plant; B. blade close-up; C. peduncle close-up; D. flower; E. adaxial and abaxial view of the flower; F. capsule; G. seed and two close-ups. 
Sánchez-Ken: Hypoxis colliculata, a new species from Mexico
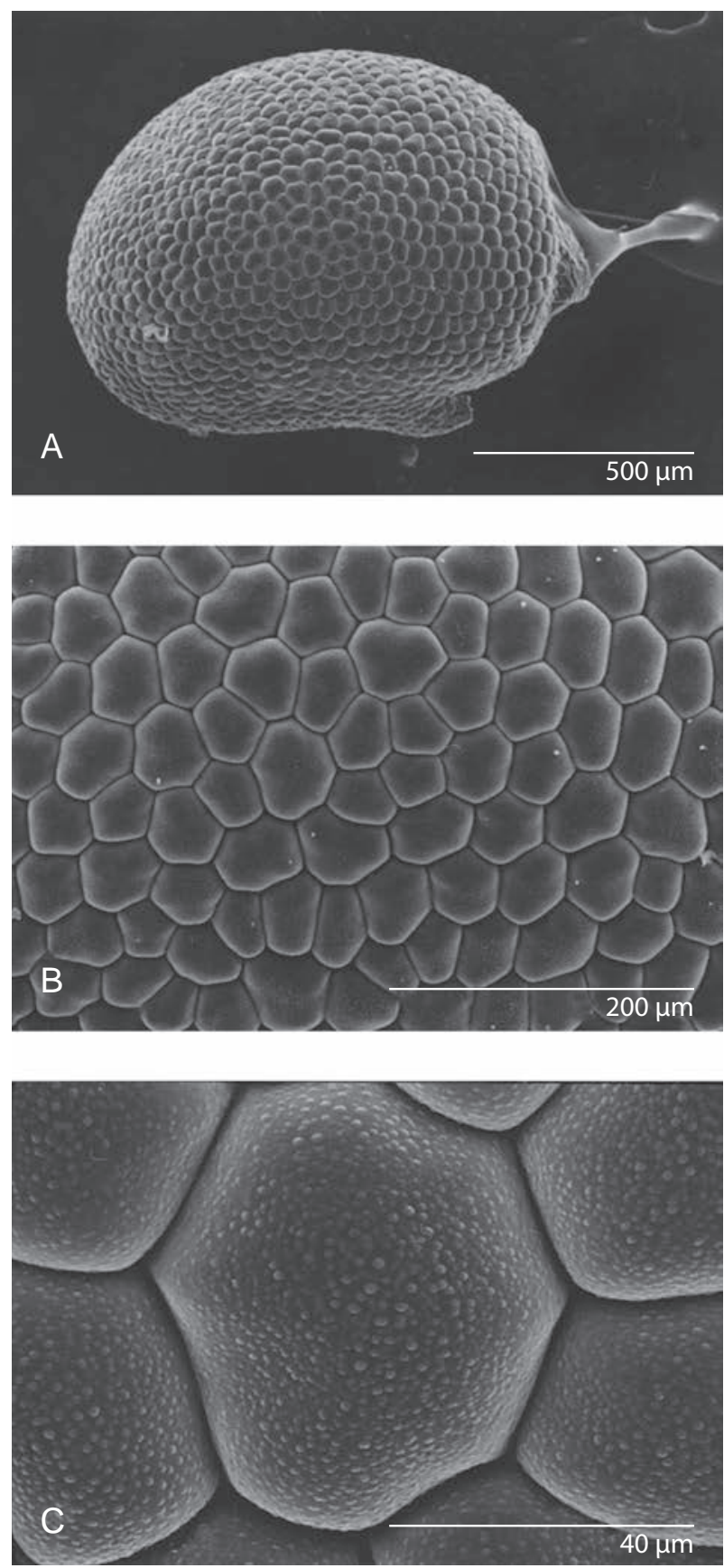

Fig. 2. A. seed; B. close up of the surface; C. close up of a cell. 
Paratypes. Chiapas, municipio San Cristóbal de las Casas, Valle to E of Las Casas, along brook on bank, 20.IV.45, E.J. Alexander 1174 (MEXU); cultivated slope in barrio Custital in San Cristóbal de las Casas, 7200 ft, 21.VI.66, R.M. Laughlin 1357 (MEXU); municipio Teopisca, 2 km al N de la Laguna Chamula, carretera Teopisca - Comitán, 1110 m s.n.m., bosque de Pinus-Quercus-Juniperus, suelo calizo, 5.VIII.89, A. García-Mendoza \& E. Martínez 4226 (MEXU). Oaxaca, distrito Nochixtlán, $7 \mathrm{~km}$ al $\mathrm{N}$ de Amatlán, $2350 \mathrm{~m}$ s.n.m., bosque de encinos, suelo pedregoso, 14.VII.86, A. García-Mendoza y F. Mérida 2623 (MEXU); distrito Teposcolula, 1.5 km al NO de Teposcolula, en la intersección del camino a Yucunama y San Andrés Lagunas, 2370 m s.n.m., pinar, suelo calizo, 9.VII.81, A. García-Mendoza 447a, 447b (MEXU); 4 km al N de Guadalupe Tixá, sobre el camino a San Andrés Lagunas, $2260 \mathrm{~m}$ s.n.m., zona deforestada a orilla de bosque de pino, suelo calizo, 15.VII.86, A. García-Mendoza y F. Mérida 2674 (MEXU).

Distribution, habitat and phenology. This new species is restricted to Mexico in the states of Chiapas and Oaxaca. It is found in oak forest and pine with Juniperus forest, on calcareous soils, at elevations between 1110 to $2440 \mathrm{~m}$. It flowers and fruits from April to August.

\section{DISCUSSION}

Hypoxis colliculata belongs to the group of species that have black, usually shiny seeds, with no exfoliative or loose cuticle (McVaugh, 1989; Herndon, 1992; Zona et al., 2009). In the Americas, eight out of the 15 species have black seeds. At the moment, four types of seed sculpturing can be recognized, such as smooth $(H$. lucens), muricate or muriculate ( $H$. hirsuta (L.) Coville, and H. pulchella Nesom), papillate or colliculate, Brackett (1923) called these rounded pebbling or tall papillae (H. decumbens, $H$. juncea, $H$. rigida Chapm., and $H$. tepicencis Brackett), and colliculate or strumose surfaces (new species). So far, none of the species in this group shows iridescence or exfoliation of the cuticle. In H. lucens and $H$. hirsuta the surface of the cells or papillae is smooth, whereas in the rest of the species the surface has tiny warts (Fig. 2C). The warts may be small and short like in $H$. colliculata or elongated as in $H$. decumbens. In the new species $H$. colliculata the seeds bear a colliculate surface, the cells are small, heterodiametric, more or less homogeneous in size, compactly arranged, not inflated or very slightly so (Figs. 2A and 2B). Winland-Szymańska (2001) used the term "colliculate with flat papillae"; 
which would be something like a mixture of the terms colliculate and tessellate (Harris \& Harris, 2001).

The new species $H$. colliculata is easily separated from the species that have seeds with smooth, muricate, muriculate, papillate or colliculate with inflated cells surfaces. Based on the characters of the seeds, the species is more closely related to $H$. colliculata are $H$. decumbens, $H$. rigida, $H$. juncea, and $H$. tepicensis, in all these species the cells of the epidermis are more isodiametric, larger and homogeneous in shape and size, and of course they are inflated.

Other characters that may help to separate the new species are the presence of fibers at the base of the corm. However this character may be difficult to observe on incomplete specimen collected without the crown of fibers. It can be suggested that age of the plant may also influence the presence of the fibers, but this needs to be confirmed.

Due to the lack of an updated key of Hypoxis for the Americas, here I present a key to the species that have black seeds. These species are found mainly from United States to Mexico, with $H$. decumbens extending from Mexico to Central and South America as well as to the Caribbean.

Key to the species with black seeds present in the Americas.

1. Seeds smooth or sometimes obscurely reticulate H. lucens McVaugh

1. Seeds with evidently sculptured surfaces.

2. Corms with a membranaceous tunic and never with fibers; seeds with a papillate or muricate surface.

3. Plants small, delicate; leaves filiform, stiff, nearly glabrous; seeds with a papillate surface H. juncea Sm.

3. Plants small, delicate to large and robust; leaves linear to linear lanceolate, laminal, pubescent; seeds with a papillate (rounded pebbles) or muricate surface.

4. Seeds with a papillate surface, papillae large, round and inflated, apex rounded H. decumbens L.

4. Seeds with a muricate surface, papillae large, rounded and inflated or thinner, dehydrated, less inflated looking like a spine, apex with smaller papillae or niplike.

5. Seeds with large and inflated papillae H. hirsuta (L.) Coville

5. Seeds with thin, dehydrated and spiny looking papillae 
2. Corms with a membranaceous tunic, with a crown of fibers, fibers scattered and up to $1 \mathrm{~cm}$ to dense and longer, rarely absent; seeds with a papillate or colliculate surface.

6. Seeds with a colliculate surface, the cells not inflated or slightly so, short, small, heterodiametric H. colliculata Sánchez-Ken

6. Seeds with a papillate surface, the cells inflated, tall, more or less isodiametric to rounded, larger than the previous option.

7. Papillae dome or round-shape, the apex blunt H. rigida Chapm.

7. Papillae conical-shape, the apex acute H. tepicensis Brackett

\section{ACKNOWLEDGMENTS}

I would like to thank F. Chiang C. for the Latin translation of the description of the new species, R. Medina L. for her comments on the manuscript. Many thanks are extended to A. Luna for the illustration and M. B. Mendoza G. for the scanning electronic microscope (SEM) images.

\section{LITERATURE CITED}

Anonymous. 2003. An update of the Angiosperm Phylogeny Group classification for orders and families of flowering plants: Angiosperm Phylogeny Group II. Bot. J. Linn. Soc. 141: 399-436.

Baker, J. G. 1878. A synopsis of Hypoxidaceae. J. Linn. Soc. 17: 93-126.

Brackett, A. 1923. Revision of the American species of Hypoxis. Rhodora 25: 120-147, 151163.

Cronquist, A. 1981. An integrated system of classification of flowering plants. Columbia University Press, New York. 1262 pp.

Dahlgren, R. M. T., H. T. Clifford \& P. F. Yeo. 1985. The families of the Monocotyledons. Springer-Verlag. Berlin. 520 pp.

Davis, J. I., S. W. Stevenson, G. Peterson, O. Seberg, L. M. Campbell, J. V. Freudenstein, D. H. Goldman, C. R. Hardy, F. A. Michelangeli, M. P. Simmons, C. D. Specht, F. VergaraSilva \& M. Gandolfo. 2004. A phylogeny of the monocots, as inferred from $r b c L$ and atpA sequence variation, and a comparison of methods for calculating jackknife and bootstrap values. Syst. Bot. 29(3): 467-510.

Espejo S., A. \& A. R. López F. 1996. Las monocotiledóneas mexicanas. Una sinopsis florística. Parte V. Consejo Nacional de la Flora de México, A.C., Universidad Autónoma Metropolitana Iztapalapa, Comisión Nacional para el Conocimiento y Uso de la Biodiversidad. México, D.F. 116 pp. 
Harris, J.G. \& M.W. Harris. 2001. Plant identification terminology. Utah: Spring Lake Publishing. 206 pp.

Herndon, A. 1992. The genus Hypoxis (Hypoxidaceae) in Florida. Florida Scient. 55: 4555.

Huft, J. J. 1994. Hypoxidaceae L. In: Davidse, G., M. Sousa S. \& A. O. Charter (eds.). Flora Mesoamericana. Vol. 6. Alismataceae a Cyperaceae. Universidad Autónoma Nacional de México. México, D.F. pp. 51-53.

Govaerts, R. 2007. World checklist of Hypoxidaceae. The Board of Trustees of the Royal Botanic Gardens, Kew. Published on the Internet http://www.kew.ogr/wcsp/monocots/ accessed/23 Sep 2009.

McVaugh, R. 1989. Hypoxis L. In: Anderson, W. R. (ed.). Flora Novo-Galiciana. Vol. 15. Bromeliaceae to Dioscoreaceae. University of Michigan Herbarium. Ann Arbor. pp. 219-227.

Nesom, G. L. 1993. A new species and new variety of Hypoxis (Hypoxidaceae) from northeastern Mexico. Phytologia 75(5): 377-381.

Rudall, P. J., M. W. Chase, D. F. Cutler, J. Rusby \& A. Y. de Bruijn. 1998 Anatomical and molecular systematics of Asteliaceae and Hypoxidaceae. Bot. J. Linn. Soc. 127: $1-42$.

Villaseñor, J. L. 2004. Los géneros de plantas vasculares de México. Bol. Soc. Bot. México 75: $105-135$.

Wiland-Szymańska, J. 2001. The genus Hypoxis (Hypoxidaceae) in Central Africa. Ann. Missouri Bot. Gard. 88(2): 302-350.

Wiland-Szymańska, J. 2006. Morphological variability of seeds in East African species of the genus Hypoxis L. (Hypoxidaceae). Biod. Res. Conserv. 1-2: 31-33.

Zona, S., J. Prince. G. Halder, R. Schwartz \& R. Vargas. 2009. A seed atlas of Hypoxis from Eastern North America. J. Torrey Bot. Soc. 136(1): 26-32.

Recibido en noviembre de 2009. 
